\title{
Exploring factors influencing dental caries preventive measures by general dental practitioners in the public oral health care service in Paraná State, Brazil
}

João Paulo Guilherme de Lima*; Tânia Harumi Uchida**; Regina Maria Pavanello***; Raquel Sano Suga Terada****; Renata Corrêa Pascotto****; Ricardo Pietrobon*****; Mitsue Fujimaki ******

\author{
* MSc in Dentistry, Universidade Estadual de Maringá \\ ** PhD Student, Universidade Estadual de Maringá \\ *** Researcher, Universidade Estadual de Maringá \\ **** Associate Professor, Universidade Estadual de Maringá \\ ***** Professor, Departament of Surgery, Duke University Medical \\ Center \\ ****** Adjunct Professor, Universidade Estadual de Maringá
}

Received Dec. 21, 2017. Approved March 13, 2018.

\begin{abstract}
This study aimed to explore the views of dentists working for the Brazilian health system, in regards to the prevention of dental caries. Semi-structured face to face interviews were held with 18 dentists working in the state of Paraná, Brazil. Data was recorded, manually transcribed and analyzed with a software, based content analysis. Results revealed 13 factors favoring prevention, of which 4 were considered new emerging factors, not previously described in the literature. Among the main factors to influence caries prevention were: the preventive conscientiousness of dentists, professional training received and the organization of the service. The results found indicated that the implementation of prevention depends on several factors such as the training received by dental students, changes in the public dental care provided by expanding the Family Health Strategy and changes in clinicians' attitudes towards prevention through more effective public policies involving the community. Descriptors: Qualitative Research. Preventive Dentistry. Dental Caries. Health Education.
\end{abstract}

\section{INTRODUCTION}

Dental caries is considered the most common chronic disease during childhood, and the main factor responsible for pain and tooth loss throughout the history of humanity ${ }^{1}$. Considered a pandemic with significant impact on the general health and social welfare of children, dental caries can lead to discomfort, malnutrition, learning difficulties, lack of concentration, speech impairment, low selfesteem, orthodontic problems, as well as feelings of guilt and shame in parentes ${ }^{2,3}$. Estimates indicate that $70 \%$ of children in developing countries have or have had dental caries 
experience, mostly untreated ${ }^{4}$.

The last national epidemiologic survey on oral diseases conducted by the Brazilian Health Ministry showed that, despite the expressive reduction in the dental caries index in all different age groups brought about by improvements in the general health care provision, the population continues to lose their teeth throughout their lives ${ }^{5,6}$. This scenario seems to indicate that relevant advances in the level of oral health in the population can only be achieved by placing more emphasis on implementing public policies directed towards prevention. Nonetheless, breaking the present curative paradigm in favor of a more preventive one, both at individual and community level, is a huge challenge that will demand a shift from the model presently provided by the national public oral health care service.

The dimension of this challenge can be observed by the number of published studies investigating caries that have been conducted in Latin American countries. While in European countries, especially in Scandinavia, the number of studies involving preventive measures implemented between 1980 and 1998 represented approximately $58.6 \%$ of the all the studies conducted on dental caries, in Latin America, they amounted to only $2.9 \%$ in the same period. This difference in focus may account for the gap between dental caries indexes found in Europe and Latin America. Furthermore, the majority of studies conducted in Latin America were either epidemiologic investigations or quantitative in nature, demonstrating that little has been discussed and done to find out the preventive awareness of dentists in the public servisse ${ }^{7,8}$. As a result, information on their perceptions and attitudes toward prevention is still scarce . $^{7}$

Studies conducted have demonstrated that the main barriers to providing preventive dental care are: lack of clinical time; high demand for curative procedures; biologicist-centered training, lack of remuneration for implementing preventive measures, shortage of materials to use with patients; and the curative vision of patients themselves ${ }^{1}$. Other studies have also shown that skepticism related to preventive measures; lack of motivation by patients and guardians; lack of professional experience; absence of preventive criteria and planning; shortage of resources and organizational support were also determining factors towards the curative vision of the service to the detriment of prevention ${ }^{4,9,10}$. In a previous systematic review using the metasummary technique, dental education and training emerged as the most important category to affect dentists' perception on how to conduct their activities ${ }^{11}$.The formation of dental professionals could improve the quality of advice, raise the level of commitment and give a new perspective on oral health advice to patients ${ }^{12}$. Knowing the reasons that drive dentists away from practicing prevention, and factors that facilitate its adoption, could, therefore, make a critical contribution towards implementing dental caries preventive programs. These programs would avoid the high costs of dental treatments and enable the prevalence of caries to be more effectively tackled ${ }^{13}$.

In Latin America as a whole, and in Brazil more specifically, no qualitative studies have been conducted so far to explore the perceptions that dentists who work for public oral health care systems have about prevention. Moreover, the reasons why dentists do not incorporate a more preventive attitude into their practice are still unclear. Therefore, the objective of this qualitative study was to explore the perceptions of dentists working for the Brazilian Unified Health System (SUS) in order to understand the main factors that positively influence the implementation of prevention. This information would be useful to 
support effective public policies to incentive professionals towards a more preventive practice.

\section{METHODS}

\section{Study design}

This exploratory, cross-sectional, qualitative study through action research was conducted with the aim to explore the main factors to influence the implementation of dental caries preventive measures by dentists in the public service. Data were collected through semistructured interviews conducted with dentists working for the Basic Health Care Units (BHUs) in the municipalities belonging to the Paraná State.

The communication with participants was performed using the Snowball technique ${ }^{14}$. This is an accepted method to achieve the convergence of opinions from experts of different areas. Thus, the final instrument should provide local health care managers with a broader view of the service, and contribute to management actions on a variety of health issues based on consensus. The findings were reported following the checklist of the Consolidated Criteria for Qualitative Research Reports $(\text { COREQ })^{15}$. The interviews were recorded, transcribed and analyzed, based on Bardin's content analysis ${ }^{16}$.

\section{Sample}

The selection criteria for the dentists participating in the study were: experience; age; education and clinical practice; forming a sample of convenience. All dentists interviewed had been working in the public service in the [texto ocultado] for at least one year. Clinicians working in public health care for less than a year were excluded from the sample because they may not have been totally familiarized with the operation of the health units where they worked, for and/or were not completely aware of the present oral health status of the residents in the area covered by their unit.

The participants were initially contacted at their place of work by telephone or e-mail. After they had accepted to participate in the study, interviews were held in their respective offices at a time of their convenience, when they signed a term of free and informed consent. Interviews were conducted "face to face" based on a semistructured script. Only the respondent and the interviewer were present during the interviews. Participation was voluntary, and participants could leave the study at any moment they wished. The final sample was defined by the saturation point of the data.

\section{Semi-structured Script}

A review of the literature was conducted, and a script for the interviews was initially elaborated based on the main studies on the theme. Improvements were performed with the assistance of researchers with previous experience in qualitative analysis. Alterations to the script were conducted based on suggestions discussed during meetings so that the questions in the final version of the script and the approaches to be used would be as free of bias as possible.

The script was composed by questions covering the following topics: the vision held by clinicians on the preventive practices conducted at BHUs, their relationship with the health care team members concerning prevention, their experience with preventive measures during the course of their training, public actions that influence the prevention of caries in the BHUs, and if any financial incentives for the provision of prevention of oral diseases existed.

\section{Data collection}

Interviews were held by only one interviewer who received training on the themes 
of qualitative research and semiotics of communication before the study began. The interviewer was familiar with the terms used by the respondents and their work routine. To guarantee impartiality during interviews and data analysis, there were no conflicts of interest between the interviewer and respondents. Before interviews began, respondents were fully informed about the identity and training of the interviewer, the importance and the objectives of the study, and how the interview would be conducted.

The interviews lasted for about 20 minutes and were recorded with participants' authorization. A portable voice recorder (Samsung GT-S3350) and the Camtasia Studio 7.1.1 build 1785 software were used to record the interviews. The interviews were transcribed manually by the interviewer, so that they could be read in full, allowing them to be edited without, however, being altered. The transcriptions were revised by a senior researcher with experience in qualitative methodologies. Data confidentiality was assured by not identifying the transcriptions, and extreme care was taken not to expose any details that could identify the respondents.

Although the interviews were conducted according to the semi-structured script, the interviewer could lead the conversation as he saw fit in order to obtain the desired information, without straying from the initial proposal of the study. Within this approach, participants were free to say whatever they felt to be important about the theme.

\section{Data analysis}

The text is used as a means of expression of the individual, based on which the analyst attempts to categorize units (words or phrases), whose repetitions are inferred from expressions representing them. All the categories that emerged from the interviews were agreed upon by all the participating authors. Content analysis, through systematic and objective procedures to describe the content of messages, aims to obtain indicators (quantitative or not) that may allow the inference of knowledge based on the conditions for the production and reception of these messages ${ }^{16}$.

Thus, statements were pre-codified and pre-analyzed transversally and intuitively by the interviewer throughout the study. The interviews were coded and analyzed by using Bardin's categorical technique with the assistance of The Qualitative Data Analysis \& Research Software 7.0 (Atlas.ti® Scientific Software Development, Berlim, Alemanha), assists in the qualitative analysis of textual data, coding of speeches, organization of codes and families, and facilitating the management of large volumes of qualitative data. Key expressions and central ideas, denominated registration units, were identified in the context unit. The registration units were grouped according to the same, equivalent or complementary categories of data (Figure 1). The incidence of these categories allowed the findings to be organized, and a descriptive numerical approach to the empiric material to be used. In addition, the registration units were quantified.

The study was previously submitted to and approved by the Permanent Ethics Committee on Research Involving Human Beings at the State University of Maringá, Brazil (protocol CAAE $\mathrm{N}^{\circ}$ 0299.0.093.000-11).

\section{RESULTS}

The final sample consisted of 18 dentists, 8 men, and 10 women, with a mean age of 39 years. Concerning their responsibilities in the public oral health system, 6 participants were clinicians hired to work $20 \mathrm{~h} /$ week, 7 belonged to the Family Health Strategy (FHS), 4 worked both as 


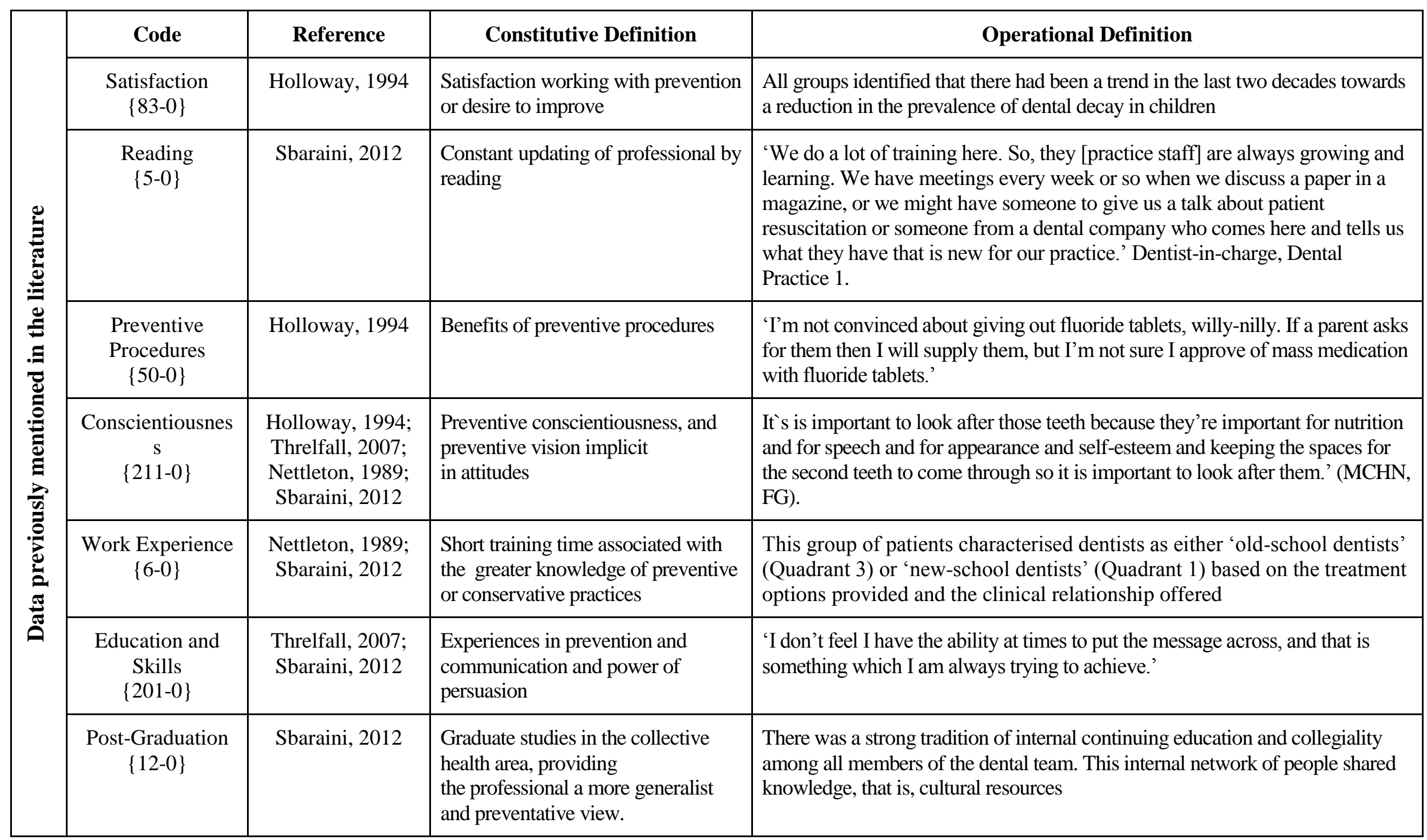

Figure 1. Organization and definition of the categories of data (codes) that indicate those factors that facilitate the provision of preventive measures by dentists in the public service and their frequency of occurrence during the interviews

continues... 


\begin{tabular}{|c|c|c|c|c|}
\hline \multirow{3}{*}{ 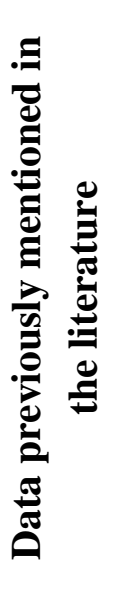 } & Code & Reference & Constitutive Definition & Operational Definition \\
\hline & $\begin{array}{l}\text { Cost-Benefit } \\
\quad\{39-0\}\end{array}$ & $\begin{array}{l}\text { Holloway, 1994; } \\
\text { Sbaraini, } 2012\end{array}$ & $\begin{array}{l}\text { Low-cost prevention associated with a } \\
\text { great biological or financial benefit }\end{array}$ & $\begin{array}{l}\text { So, then it became easy. I had the duraphat here. I had the high } \\
\text { concentration fluoride toothpaste here. I had the stuff you need for saliva } \\
\text { testing. I had the computer system. I had digital imaging. So, it was not a } \\
\text { hard thing to do. } \\
\text { It was more the mental thing and thinking, 'this is what I am doing' and I } \\
\text { had to sell it to my staff and then I was selling it to my patients }\end{array}$ \\
\hline & $\begin{array}{l}\text { Teamwork } \\
\{51-0\}\end{array}$ & $\begin{array}{l}\text { Threlfall, 2007; } \\
\text { Holloway, 1994; } \\
\text { Sbaraini, } 2012\end{array}$ & $\begin{array}{l}\text { Benefits of working as a team, } \\
\text { especially with oral health technicians }\end{array}$ & $\begin{array}{l}\text { "It's my therapist you should to talk about dental health education, not } \\
\text { me" }\end{array}$ \\
\hline \multirow{4}{*}{ 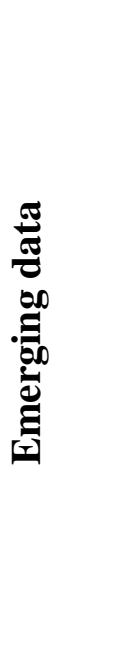 } & $\begin{array}{l}\text { Health Education } \\
\qquad\{10-0\}\end{array}$ & & $\begin{array}{l}\text { Educate the population about } \\
\text { prevention. }\end{array}$ & $\begin{array}{l}\text { "Our team has focused on health education, working together with } \\
\text { community workers and teachers in schools." }\end{array}$ \\
\hline & $\begin{array}{l}\text { Family Health } \\
\text { Strategy } \\
\{82-0\}\end{array}$ & & $\begin{array}{l}\text { Family and community care prioritizing } \\
\text { actions on prevention. }\end{array}$ & $\begin{array}{l}\text { "We go on home visits, apply questionnaires asking how often people } \\
\text { brush their teeth each day, use dental floss and go to the dentist. We } \\
\text { provide the guidelines at people's homes with the Health Community } \\
\text { Agents." }\end{array}$ \\
\hline & $\begin{array}{c}\text { Coverage for } \\
\text { Preventive Action } \\
\{9-0\}\end{array}$ & & $\begin{array}{l}\text { Change of the system of pro-fessional } \\
\text { assessment, covering more } \\
\text { preventive procedures. }\end{array}$ & $\begin{array}{l}\text { "There is goal agreed with Regional Health Administration for supervised } \\
\text { brushing each year." }\end{array}$ \\
\hline & $\begin{array}{c}\text { Support } \\
\{42-0\}\end{array}$ & & Availability of materials for prevention. & $\begin{array}{l}\text { "The municipality helps distribute toothpaste, toothbrush, and illustrative } \\
\text { material." }\end{array}$ \\
\hline
\end{tabular}

Figure 1. Organization and definition of the categories of data (codes) that indicate those factors that facilitate the provision of preventive measures by dentists in the public service and their frequency of occurrence during the interviews 
clinicians in the FHS and as oral health coordinators in their respective areas, while 1 worked both for $20 \mathrm{~h} /$ week as a clinician and as oral health coordinator.

Respondents had been working as dentists for a mean time of 17 years, with an average of 11 years in the public service. Twelve respondents had graduated from state dental schools, while 6 from private dental schools. Eleven dentists were specialists in different clinical areas, while 7 in public oral health. Six respondents were fully dedicated to public service, while 12 also worked in their own private practice.

From the analysis of participants' views on the factors that facilitate prevention, a total of 13 codes considered to facilitate provision emerged from the analysis of the context units. Of these, four new codes not previously reported in the literature emerged from the analysis. As Bardin's categorical analysis is based on the incidence of categories mentioned in the text to propose inferences and interpretations, the number of occurrences of each category are also presented (table 1).

Table 1. Frequency of the categories of data indicating the factors that facilitate the prevention by dentists in the public service

\section{Categories of data}

$\begin{array}{ll} & \text { Conscientiousness }\{211-0\} \\ & \text { Education and communicative skill }\{201-0\} \\ & \text { Satisfaction }\{83-0\} \\ & \text { Teamwork }\{51-0\} \\ \text { Data previously reported }\{658-0\} & \text { Preventive Procedures }\{50-0\} \\ & \text { Cost-Benefit }\{39-0\} \\ & \text { Work Experience }\{6-0\} \\ & \text { Post-Graduation }\{12-0\} \\ & \text { Reading }\{5-0\} \\ & \text { Public Health Dentists }\{82-0\} \\ & \text { Support }\{42-0\} \\ & \text { Permanent education }\{10-0\} \\ & \text { Coverage }\{9-0\}\end{array}$

According to the participants, the main aspect to motivate dentists towards providing prevention would be their own preventive conscientiousness (211 occurrences). This assertion was frequently justified by their perception of the positive cost-benefit ratio offered by prevention, and by their view of themselves as educators; incorporating the role of educators that are concerned not only with the mouth and teeth, but also with the well-being and the quality of life of their patients.

"[...] I think that preventive work is the basis of everything [...] for patients and for the cost in the treatment units" (Participant G007).

"So, for me, the greatest incentive to do prevention is to know that those people, they will live with oral health quality"(Participant F006).

Participants also suggested that to enable 
them to carry out their preventive work better, continuous improvement of their oral health care education and communication skills (201 occurrences) would be necessary throughout their professional lives. This was evident by their understanding of the need to establish bonds with patients, to seek new strategies concerning the need for the dentist to be included in the community, and to educate patients in regards to the benefits of prevention.

"You cannot give up teaching or you will not change their habits, you have to use all the strategies available and repetition [...]" (Participant E015).

"Then, I think that it is a very nice contact, having a dentist in the community, participating in group meetings, the hypertensive, the diabetic, [...] in schools, and then, when they come to the unity, you have a stronger bond, don't you? They treat you well; they have no fear to talk [...]"'(Participant D010).

Among the new emerging factors specifically related to the reality of these dentists working in providing public oral health care, the extension of the Family Health Strategy (82 occurrences) was also considered a key contributor to enhance preventive measures, due to the possibility of dentists sharing their working time between clinical care and the dispersion period, destined for household visits and the planning of public actions. Among the FHS attributes mentioned by respondents were the multidisciplinary professional actions, state and municipal investment in the support structure, professional qualification, and change in the care model.

"[...] I think they are betting more cards on the FHS and not on the conventional system [...]" (Participant E011).

"The city and the state are offering us courses that incentive prevention, there are a lot of resources for that [...] (Participant G012).

\section{DISCUSSION}

To the best of our knowledge, this is the first exploratory qualitative study conducted in Latin America to assess the view held by dentists working for a public oral health care system on the prevention of dental caries. The pioneering aspect of this study arises from the use of a qualitative methodology to study in depth the factors that facilitate the provision of dental caries preventive measures, taking into consideration the particularities of the Brazilian Unified Health System (SUS).

Clinicians working for the public sector, who have the daily task of caring for the oral health of the community in general, are particularly well placed to share their views on what is happening in regards to prevention in the public service. Finding themselves between policy makers and the population they care for, they can effectively contribute to the understanding of the reasons why prevention, particularly dental caries prevention, seems to be so difficult to be achieved in practice.

The scenario of public oral health care provision in Brazil is in the process of change. The national oral health care policy, also known as Smiling Brazil, implemented in 2004, defined oral health care provision as one of the 4 priority areas of the SUS. This policy had changed the concept of oral health care in Brazill ${ }^{17}$, by pursuing the goal of a comprehensive health care system envisaged for the SUS when it was created ${ }^{18}$. Prevention and health care promotion are unquestionably the logical way forward to improve oral health indexes of the population in general. However, prevention continues to be elusive, with the stakeholders in the process placing the responsibility for its implementation elsewhere. Hence, prevention must be a priority within health care management instruments at 
municipal, state and federal level. Surveys on related themes should be conducted in search for evidence capable of expanding the scope of preventive measures and the promotion of health within the health care system ${ }^{19}$.

The preventive conscientiousness was the most prevalent factor to influence prevention. When we observe clinicians' discourses, they demonstrated awareness of the advantages prevention could bring, not only to the population but also to the public system as a whole. Professional conscientiousness has been shown to be an important factor to influence prevention and has directly or indirectly been present in several previous qualitative studies on the theme $e^{4,9,20,21,22,23}$. Adequate knowledge about the biological and social impact of dental caries was observed in the speech of all the dentists interviewed, also in agreement with the previous studies $^{9,20}$. During the interviews, clinicians pointed out the positive biological and financial benefit of prevention, in agreement with the findings of Holloway e Clarkson $(1994)^{22}$. Particularly, the positive cost/benefit impact to SUS resulting from prevention was strongly evident in our analysis, a finding not previously mentioned. This may be explained by the fact that the majority of previous studies were conducted either in private offices ${ }^{7,10,11}$ or public systems different from that found in Brazil ${ }^{4,23}$. The majority of the participants, when taking on the role of health care educators, also demonstrated a strong preventive conscientiousness, corroborating the findings of Nettleton $(1989)^{23}$.

Despite showing strong preventive conscientiousness, what dentists say may not directly represent what they actually do in their clinical practice. The very high number of occurrences (211) of expressions indicating preventive conscientiousness in their discourses seems to suggest that although clinicians are fully aware of the importance of prevention, they are also critical of the difficulties to its implementation. Some of the responsibility can be attributed to the local politicians, who put pressure on dentists to perform curative procedures and achieve previously defined targets. It is not uncommon for politicians to be more concerned to improve their electoral chances rather than pursue more sensible policies. Another factor to account for the high number of occurrences of preventive conscientiousness displayed by clinicians is the fact that they may have responded in a way that would be expected from public dentists. This conflicting situation between what is said and what is done is a good representation of the present status of public oral health care provision in this country.

Preventive conscientiousness was identified in this study by the value placed on it and the effect on the performance of self-care, crucial to the effectiveness of prevention. This has also been observed in previous studies ${ }^{9,20,21,23}$, in which authors highlighted the importance of patients' conscientiousness of the preventive guidance provided by dentists, generating either professional satisfaction or frustration $^{24}$. In a qualitative study conducted with oral health care technicians, it was observed that these professionals possess a comprehensive understanding of oral health maintenance in relation to the necessity to provide prevention. According to theses professionals, prevention is "the beginning of everything", which can be understood as the basic dental treatment priority ${ }^{25}$.

Apart from the preventive conscientiousness, another factor to have a broad impact on clinicians attitude towards prevention was their training. Clinicians are still being trained from a curative standpoint, a biomedical model consolidated by the Flexner's report ${ }^{24}$. 
Today, however, this approach is being challenged by the objectives proposed by new curricular guidelines established by the Brazilian Ministry of Education. This has resulted in a dualism, evidenced by the presence of factors such as biologicism, and the need for better health care education and communication skills, identified as extremely important factors for providing prevention. This was evident from the search for strategies that could facilitate the understanding of messages transferred by dentists to patients, reinforcing the importance of clinicians in the process, a factor also observed previously $^{9,22}$.

However, a previous focus group study conducted with dentists showed that respondents considered dental education to be deficient in the development of communication and interpersonal skills; that many dental students are not aware of the social aspects involved in patient's health and are not adequately prepared to embrace an interdisciplinary socially-based health care education ${ }^{26}$. Health care education should aim at the development of autonomous professionals in health care provision, not by imposing technical-scientific knowledge, but through the understanding of individual health care needs ${ }^{27}$. Education, in general, should also be a humanizing process, in which knowledge should be built together with the learner, slowly and progressively ${ }^{28}$. In practice, oral health care education requires professional commitment, dedication, and above all persistence. According to Freire $(1996)^{28}$, the acquisition of education should aim at seeing to the needs of the population within their own realities, in order to generate conflicts in the individual, making them to rethink their culture and create the means to change their own conduct ${ }^{28}$. This highlights the belief in proper health care education as the main way forward to improve oral health care provision and develop more realistic strategies to change eating and behavioral habits.

The Brazilian SUS, in its organization and work relations, has been demonstrated to have an important influence on dentists' perception concerning the provision of preventive measures. The FHS, with its $40 \mathrm{~h} /$ week working structure, was seen to favor the provision of prevention. This was because dentists in the FHS can share their working time between clinical care and dispersion. In this circumstance, it is common for dentists to meet the same patients on these two different occasions, facilitating the reinforcement of preventive measures, and strengthening the bond of trust between them. Although the 40 $\mathrm{h}$ /week working arrangement does not prevent many dentists from working in the private sector, their responsibilities in the public service require dedication. Moreover, as dentists are better paid, their supplementary activities in the private sector is pushed to a secondary level.

Another factor to favor the provision of prevention by the FHS is the support nationally offered by the SUS, which includes better physical structure, more adequate clinical and illustrative materials, didactical and audio-visual resources for oral health care guidance, as well as professional training courses. Within SUS, the FHS has resulted in the reorientation of the health care model provided, with multiprofessional teams being implemented in the BHUs. These teams are responsible for a defined number of families located within a particular geographic áre $^{29}$. Teams work with different actions for the promotion health, prevention of diseases, treatment of the most common diseases and injuries, and the maintenance of health of this community as a whole ${ }^{30}$.

Although dental surgeons often find it difficult to find their role without facing the social determinants of health, which are "conditions in which people are born, grow, live, work and grow old"31 researchers, educators, 
professionals and academics to improve their look and update them beyond the biological process involved, integrating them with the social space they live ${ }^{32}$. Thus, public health care policies that include oral health care actions within the FHS can bring about the reorganization of the basic oral health care, change professional practices, and transform the health of the population ${ }^{33}$.

\section{CONCLUSIONS}

The results of the present study indicate that Dental schools should emphasize prevention throughout their courses, by placing it high on the agenda of daily clinical practice during graduation. Moreover, although the SUS has been developing its structure and incentives, the FHS arrangement, which encourages the implementation of oral health care teams working within defined areas, should be extended to favor the more effective practice of prevention. These two initiatives combined could serve as the springboard for the fundamental changes to bring dental caries indexes closer to those found in more developed nations. Thus, further qualitative studies such as the present one, conducted with clinicians and health care team members in the dental area, are of fundamental importance to develop and assess strategies for the implementation of public policies towards the prevention of diseases and the promotion of health.

\section{RESUMO}

Explorando fatores que influenciam na prevenção da cárie dentária no atendimento odontológico do serviço público do Estado do Paraná, Brasil

A cárie é a doença crônica mais comum na infância e leva a perdas dentárias ao longo da vida. Entretanto, a percepção dos cirurgiõesdentistas (CDs) quanto sua prevenção, ainda é pouco explorada. O objetivo do estudo foi explorar as percepções dos CDs que trabalham no Sistema Único de Saúde, no que diz respeito à prevenção da cárie dentária, contribuindo para políticas públicas efetivas, a partir da identificação dos fatores que levam os CDs a uma maior conscientização preventiva. Foram realizadas entrevistas semiestruturadas com 18 CDs atuantes nos municípios do Paraná. As entrevistas foram realizadas face a face, conduzidas por um roteiro e gravadas. A transcrição foi realizada de forma manual e analisada segundo o método de análise de conteúdo. Os resultados apontaram treze fatores facilitadores à prevenção, sendo quatro deles fatores emergentes, não descritos anteriormente pela literatura. Dentre os principais fatores que influenciam a prevenção da cárie: consciência preventiva dos CDs, formação acadêmica do profissional e organização do serviço. Assim, a implementação da prevenção depende de vários fatores, como a formação recebida por estudantes de Odontologia, mudanças no atendimento público odontológico e nas condutas adotadas pelos CDs e políticas públicas efetivas que envolvam a comunidade.

Descritores: Pesquisa Qualitativa. Odontologia Preventiva. Cárie Dentária. Educação em Saúde.

\section{REFERENCES}

1. Ghasemi H, Murtomaa H, Torabzadeh H, Vehkalahti MM. Knowledge of and Attitudes towards Preventive Dental Care among Iranian Dentists. Eur J Dent. 2007; 1(4):222-9.

2. Topaloglu A, Eden E, Frencken JE. Managing dental caries in children in Turkey - a discussion paper. BMC Oral Health. 2009; 9(32):1-9.

3. Beiruti N. Views on oral health care strategies. East Mediterr Health J. 2005; 11(1-2):209-16.

4. Gussy MG, Waters E, Kilpatrick NM. A qualitative study exploring barriers to a model of shared care for pre-school children's oral health. Br Dent J. 2006; 
201(3):165-70.

5. Roncalli AG. Projeto SB Brasil 2010 Pesquisa Nacional de Saúde Bucal revela importante redução da cárie dentária no país. Cad Saúde Pública. 2011; 27(1):4-5.

6. Brasil. Ministério da Saúde (MS). Secretaria de Atenção à Saúde. Departamento de Atenção Básica. Projeto SB Brasil 2010: Pesquisa Nacional de Saúde Bucal Resultados Principais. Brasília: Ministério da Saúde; 2011.

7. Almeida GCM, Ferreira, MAF. Saúde bucal no contexto do Programa Saúde da Família: práticas de prevenção orientadas ao indivíduo e ao coletivo. Cad Saúde Pública. 2008; 24(9):2131-40.

8. Chaves SCL, Vieira-da-Silva LM. As práticas preventivas no controle da cárie dental: uma síntese de pesquisas. Cad Saúde Pública. 2002; 18(1):129-39.

9. Threlfall AG, Hunt CM, Milsom KM, Blinkhorn AS. Exploring factors that influence general dental practitioners when providing advice to help prevent caries in children. Br Dent J. 2007; 202(4):1-4.

10. Dyler TA, Robinson PG. General health promotion in general dental practice - The involvement of the dental team Part 2: A qualitative and quantitative investigation of the views of practice principals in South Yorkshire. Br Dent J. 2006; 201:45-51.

11. Suga USG, Terada RSS, Ubaldini ALM, Fujimaki M, Pascotto RC, Batilana AP, Pietrobon R, Vissoci JRN, Rodrigues CG. Factors that drive dentists towards or away from dental caries preventive measures: Systematic Review and Metasummary. PLoS ONE. 2014; 9(10). doi: 10.1371/journal.pone.0107831

12. Arpalahti I, Tolvanen M, Pienihakkinen K. Comparing Health Promotion Programs in Public Dental Service of Vantaa, Finland: A
Clinical Trial in 6-36 Month-Old Childreen. 2013: 757938. doi: 10.1155/2013/757938.

13. Petersen PE, Bourgeois D, Ogawa $H$, Estupinan-Day S, Ndiaye C. The global burden of oral diseases and risks to oral health. Bull World Health Organ. 2005; 83: 661-9.

14. Biernacki P, Waldorf D. Snowball sampling: problems and techniques of chain referral sampling. In: Sociological Methods and Research. 1981; 10:141-63.

15. Tong A, Sainsbury P, Craig J. Consolidated criteria for reporting qualitative research (COREQ): a 32-item checklist for interviews and focus groups. Int J Qual Health Care. 2007; 19(6):347-357.

16. Bardin L. Análise de Conteúdo. $7^{\mathrm{a}}$ Edição. São Paulo; 2011.

17. Pucca Jr GA, Lucena EH, Cawahisa PT. Financing national policy on oral health in Brazil in the context of the unified health system. Braz Oral Res. 2010; 24(Suppl 1):26-32.

18. Pucca Jr GA, Gabriel M, de Araujo ME, de Almeida FCS. Ten Years of a National Oral Health Policy in Brazil: Innovation, Boldness, and Numerous Challenges. J Dent Res. 2015; 94(10):1333-7.

19. Albuquerque TIP, Sá RMPF, Araújo Jr JLAC. Perspectivas e desafios da "nova" Política Nacional de Promoção da Saúde: para qual arena política aponta a gestão? Ciênc Saúde Colet. 2016; 21(6):1695-1705.

20. Sbaraini A. What factors influence the provision of preventive care by general dental practitioners? Br Dent J. 2012; 212(11):1-8.

21. Humphreys RE, Richards W, Gill P. Perception of first year foundation dentists on oral health education and its role in general dental practice. Br Dent J. 2010; 209(12):601-6. 
22. Holloaway PJ, Clarkson JE. Cost: Benefit of prevention in practice. Int Dent J. 1994; 44(4):317-22.

23. Nettleton S. Dentists and dental health education: a study of the perceptions of 28 community dentists. Community Dent Health. 1989; 6(1):47-60.

24. Chaves MM. Educação das profissões de saúde: perspectivas para o século XXI. Rev Bras Educ Med. 1996; 20(1):21-27.

25. Uchida TH, Terada RSS, Tenuta LMA, Fujimaki M. Práticas preventivas realizadas por Técnicos em Saúde Bucal: um estudo qualitativo. Rev Abeno. 2006; 16(1),110-24.

26. Mattos GCM, Gallagher JE, Paiva SM, Abreu MHNG. Perception of 'Comprehensiveness of Care': a qualitative study amongst dentists in the Brazilian Health System. Braz Oral Res. 2015; 29(1):1-7.

27. Souza IPMA, Jacobina RR. Educação em saúde e suas versões na história brasileira. Rev Baiana Saúde Pub. 2009; 33(4):618-27.

28. Freire P. Pedagogia da autonomia: saberes necessários à prática educativa. 25ª Edição. São Paulo: Paz e Terra; 1996.
29. Escorel S, Giovanella L, De Mendonça M, Magalhães H, Senna MCM. O programa de saúde da família e a construção de um novo modelo para a atenção básica no Brasil. Rev Panam Salud Pública. 2007; 21(2):164-74.

30. Brasil. Ministério da Saúde (MS). Departamento de Atenção Básica - Portal da Saúde. [Accessed: 5 June, 2016]. Available at:_http://dab.saude.gov.br/portaldab/smp como_funciona.php?conteudo=esf.

31. World Health Organization (WHO). A conceptual framework for action on the social determinants of Health. 2007. [Accessed: 19 Oct. 2017]. Available at: http://www.who.int/social_determinants/res ources/csdh_framework_action_05_07.pdf.

32. Bedos C, Apelian N, Vergnes JN. Time to Developed Social Dentistry. J Dent Res. 2017; 3(1): 109-110.

33. Matos PES, Tomita NE. A inserção da saúde bucal no Programa Saúde da Família: da universidade aos pólos de capacitação. Cad Saúde Pública. 2004; 20(6):1538-44.

\section{Correspondência para:}

Mitsue Fujimaki

e-mail:mfujimaki@uem.br

Departamento de Odontologia

Universidade Estadual de Maringá

Av. Mandacaru, 1.550

87080-000 Maringá, PR, Brasil 